Larger intravenous infusions $(13.5 \mathrm{mg}$. of lignocaine per minute) given to anaesthetized dogs produced a plasma level of $7 \mu \mathrm{g} . / \mathrm{ml}$. after $30 \mathrm{minutes,}$ though the depressant effect of such a procedure on haemodynamics was only moderate and all animals recovered satisfactorily. This probably represents the safe maximum level which might be produced in patients and agrees with the work of Scott et al. (1968). A rapid injection of $200 \mathrm{mg}$. of lignocaine produced a maximum plasma level of $13.8 \mu \mathrm{g} . / \mathrm{ml}$, and this was associated with a pronounced decrease in myocardial contractile force, and if the amount given was doubled a maximum plasma level of $27.8 \mu \mathrm{g} . / \mathrm{ml}$. was achieved with such severe diminution of myocardial contraction that death usually ensued. Death was due to failure of the heart as a pump, though electrical activity proceeded fairly normally. Dissociation of the electrical and mechanical activity of the heart has also been reported to occur when the calcium/potassium interrelations have been upset experimentally (Lee et al., 1966). This implies that lignocaine in toxic amounts interferes with the process of contraction of the cardiac muscle, and preliminary work suggests that this may be due to interference with calcium uptake by the sarcoplasmic reticulum (Baird and Binnion, unreported observations). Certainly substances such as adrenaline and isopren- aline increase calcium uptake by the sarcoplasmic reticulum and have a positive inotropic action, whereas lignocaine and other myocardial depressants like sodium pentobarbitone (Lain et al., 1968) reduce calcium uptake. It is the release of this calcium from the sarcoplasmic reticulum which causes the actin-myosin interaction and consequent muscle contraction.

We thank Astra A.B., Sweden, and especially Dr. B. Ortengren, for the lignocaine estimations,

Requests for reprints should be addressed to P. F. Binnion.

\section{REFERENCES}

Binnion, P. F. (1968). British Medical fournal, 2, 470.

Gianelly, R., Van Der Groeben, J. O., Spivack, A. P., and Harrison, D. C. (1967). New England fournal of Medicine, 277, 1215.

Jewitt, D. E., Kishon, Y., and Thomas, M. (1968). Lancet, 1, 266.

Lain, R. F.; Hess, M.' L., Gertz, E. W., and Briggs, F.' N. (1968). Circulation Research, 23, 597.

Lee, Y. C. P., Richman, H. G., and Visscher, M. B. (1966). American fournal of Physiology, 210, 499.

Schumacher, R. R. Lieberson, A. D., Childress, R. H., and Williams, J. F. (1968). Circulation, 37, 965.,

Scott, D. B., Jebson, P. J., Vellani, C. W., and Julian, D. G. (1968). Lancet, 2, 1209.

Stannard, M., Sloman, G., and Sangster, L. (1968). British Medical Fournal, 2, 468.

\title{
Thyroid Function in Addison's Disease
}

\author{
M. N. MAISEY,* M.B., B.SC., M.R.C.P. ; M. H. LESSOF, $†$ M.A., M.D., F.R.C.P.
}

\begin{abstract}
Summary : Clinical evidence of a thyroid disorder was present in 10 out of $\mathbf{4 0}$ patients with Addison's disease. Though the remaining 30 patients had no clinical evidence of thyroid disease, six (out of 15 tested) had thyroid microsomal antibodies and a considerably impaired response to thyrotrophin. These changes are interpreted as very early indications of developing thyroid failure. When circulating microsomal antibodies are found this seems to indicate the presence of established thyroid disease.
\end{abstract}

\section{Introduction}

The clinical association between Addison's disease of the idiopathic type and various thyroid disorders is well established (Falta, 1912 ; Schmidt, 1926 ; Carpenter et al., 1964). Schmidt (1926) found lymphocytic infiltration in the thyroid gland at necropsy in two cases of Addison's disease and postulated that this type of change might eventually lead to hypothyroidism. Irvine (1968) studied 46 patients with idiopathic Addison's disease and found thyroid abnormalities in nine and thyroid microsomal antibodies in 21 . Nevertheless, the clinical significance of the finding of antithyroid antibodies remains uncertain.

\section{Methods}

The study began with 40 patients who had Addison's disease, which was regarded as idiopathic, since there was no evidence

* Endocrine Registrar, Guy's Hospital, London S.E.1.

t Physician, Guy's Hospital, London S.E.1. of tuberculosis or of any other specific cause. Ten also showed clinical evidence of thyroid disease-two had myxoedema, five thyrotoxicosis, one a nodular goitre, one Hashimoto's disease, and one thyroiditis. Fifteen of the remaining 30 patients who did not have clinical evidence of thyroid disease agreed to attend for further investigation of their thyroid function. These investigations included fluorescent autoantibody tests carried out by applying serum to sections of various snapfrozen tissues and then staining for deposited globulin. An estimation of the serum protein-bound iodine level was also included, and so was a four-hour ${ }^{132} \mathrm{I}$ thyroid uptake test carried out both before and 18 to 24 hours after stimulation with a single intramuscular injection of 2.5 units of thyrotrophin (Thytropar). This last was regarded as a test of thyroid reserve (Hobbs et,al., 1963). Five patients who had Addison's disease of tuberculous origin were assessed in the same way, the results being compared with those found in 17 control subjects between the age of 15 and 59 years who had had thyrotrophin stimulation tests but did not show any evidence of either thyroid or adrenal disease.

\section{Results}

The details of the patients and results of the tests are shown in the Table. The cause of the Addison's disease was attributed to tuberculosis if calcification was present in the adrenal area (all five cases). Evidence of active tuberculosis was present elsewhere in two of these five cases. The remaining 15 patients were regarded as having idiopathic Addison's disease. Cinculating autoantibodies directed against the adrenal cortex were not 
found in the tuberculous cases but were present in 12 of the 15 cases in the idiopathic group. Four women and two men with idiopathic Addison's disease were found to have circulating antibodies to thyroid microsomes.

\begin{tabular}{|c|c|c|c|c|c|c|c|}
\hline $\begin{array}{l}\text { Case } \\
\text { No. }\end{array}$ & $\begin{array}{c}\text { Age } \\
\text { and Sex }\end{array}$ & $\begin{array}{l}\text { Antibody } \\
\text { Thyroid }\end{array}$ & $\begin{array}{l}\text { Antibody } \\
\text { Adrenal }\end{array}$ & $\begin{array}{c}\text { P.B.I. } \\
(\mu \mathrm{g} .1 \\
100 \mathrm{ml} .)\end{array}$ & $\begin{array}{l}\text { Length } \\
\text { of } \\
\text { History } \\
\text { (Years) }\end{array}$ & $\begin{array}{c}\text { 4-hr } \\
\text { 132I } \\
\text { Uptake } \\
(\%)\end{array}$ & $\begin{array}{c}\text { Increment } \\
\text { after } \\
\text { T.S.H. } \\
(\%)\end{array}$ \\
\hline $\begin{array}{l}1 \\
2 \\
3 \\
4 \\
5 \\
6 \\
\end{array}$ & $\begin{array}{cc}19 & F \\
20 & M \\
43 & M \\
47 & F \\
50 & F \\
50 & F \\
\end{array}$ & $\begin{array}{c}+ \\
+ \\
+ \\
+ \\
++ \\
++\end{array}$ & $\begin{array}{c}+ \\
++ \\
0 \\
+ \\
+ \\
++ \\
\end{array}$ & $\begin{array}{c}6.4 \\
5 \cdot 2 \\
6 \cdot 3 \\
(9 \cdot 6) \\
4 \cdot 3 \\
3.8 \\
\end{array}$ & $\begin{array}{c}6 / 12 \\
1 \\
16 \\
9 \\
5 \\
11 \\
\end{array}$ & $\begin{array}{r}20.7 \\
27.5 \\
18.0 \\
4.5 \\
19.0 \\
15.9 \\
\end{array}$ & $\begin{array}{r}9.0 \\
-7.5 \\
-4.5 \\
7.5 \\
3.6 \\
7.1 \\
\end{array}$ \\
\hline $\begin{array}{l}7 \\
8 \\
9 \\
9 \\
10 \\
11 \\
12 \\
13 \\
14 \\
15 \\
16^{*} \\
17^{*} \\
18^{*} \\
19^{*} \\
20^{*}\end{array}$ & $\begin{array}{cc}17 & M \\
17 & M \\
21 & M \\
23 & M \\
29 & M \\
32 & M \\
35 & F \\
41 & M \\
47 & F \\
39 & F \\
44 & M \\
58 & M \\
59 & F \\
59 & F\end{array}$ & $\begin{array}{l}0 \\
0 \\
0 \\
0 \\
0 \\
0 \\
0 \\
0 \\
0 \\
0 \\
0 \\
0 \\
0 \\
0\end{array}$ & $\begin{array}{c}++ \\
+ \\
0 \\
+ \\
++ \\
0 \\
+ \\
+ \\
+ \\
0 \\
0 \\
0 \\
0 \\
0\end{array}$ & $\begin{array}{l}3.8 \\
6.3 \\
5.3 \\
5.9 \\
9.7 \\
5.3 \\
5.3 \\
6.5 \\
4.3 \\
6.8 \\
7.1 \\
7.5 \\
4.7 \\
4.7\end{array}$ & $\begin{array}{r}8 \\
2 \\
2 \\
6 \\
7 \\
10 \\
9 \\
4 \\
1 \\
14 \\
18 \\
8 \\
13 \\
6\end{array}$ & $\begin{array}{l}12.5 \\
21.6 \\
26.5 \\
15.2 \\
10.0 \\
9.0 \\
12.5 \\
26.8 \\
22.0 \\
18.8 \\
13.7 \\
20.0 \\
16.4 \\
16.4\end{array}$ & $\begin{array}{c}17.5 \\
26.9 \\
10.8 \\
13.4 \\
11.8 \\
17.0 \\
11.1 \\
16.9 \\
11.7 \\
19.6 \\
26.6 \\
5.8 \\
11.1 \\
-0.4\end{array}$ \\
\hline
\end{tabular}

When the different groups were compared we found no significant difference in the initial thyroid uptake of ${ }^{132} \mathrm{I}$, though there was an unexpectedly low uptake in one patient (Case 4). When thyrotrophin was injected, however, the uptake of radioiodine did not show the expected increase in the group of patients with antithyroid antibodies, whereas those with "idiopathic" disease who had no antibodies responded normally, and so did the control group (see Chart). All the patients studied were clinically euthyroid, and the serum protein-bound iodine showed no pronounced difference between the various groups.

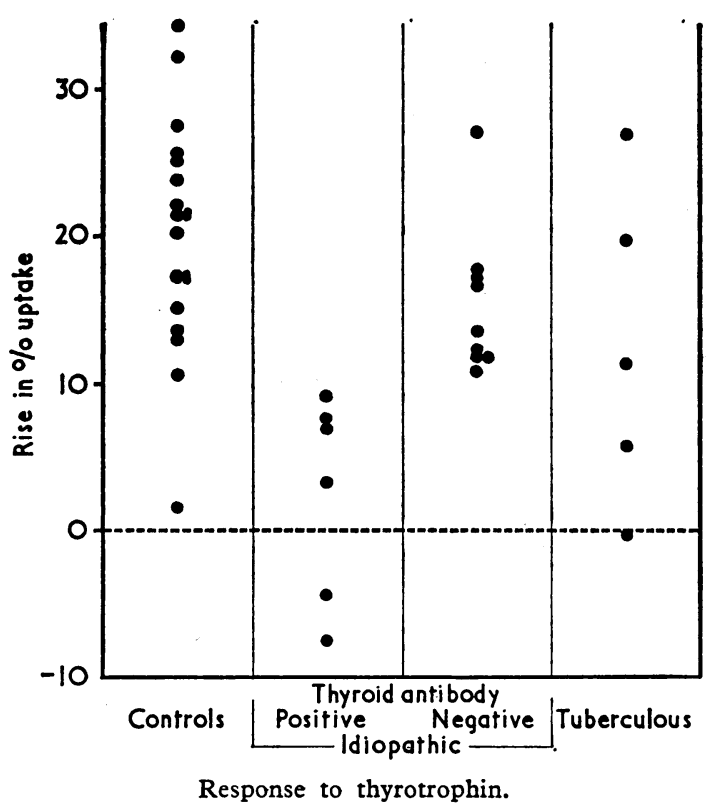

Two patients with Addison's disease of tuberculous origin (Cases 18 and 20) showed little response to thyrotrophin. The difference from the control group was not statistically significant. Lymphocytic infiltration of the thyroid has, however, been demonstrated in cases of tuberculous Addison's disease (Carpenter et al., 1964 ; Stevens and Maisey, 1969). Lymphocytic infiltration of the thyroid may also oocur (Williams and Doniach, 1962) in otherwise healthy subjects, particularly in the older age group. Both of these patients were over 55 years.

\section{Discussion}

The frequent finding of antiadrenal antibodies in idiopathic Addison's disease (Anderson et al., 1957 ; Irvine, 1968) favours the belief that these cases are largely autoimmune in origin. In support of this view Colover and Glynn (1958) have shown that an autoimmune adrenalitis could be produced in rats by immunizing them with adrenal tissue and Freund's adjuvant. The lymphocytic adrenalitis induced experimentally by Colover and Glynn resembles that found in Addison's disease by Anderson et al. (1957), Irvine et al. (1967), and Stevens and Maisey (1969). Furthermore, idiopathic Addison's disease is often associated with other lymphocytic or autoallergic disorders such as pernicious anamia, various thyroid diseases, and hypoparathyroidism (Irvine, 1968).

The association of this disorder with lymphocytic disease of the thyroid has come to be well accepted since Schmidt's original description, but mild thyroid disease is easily missed. There are obvious advantages in identifying patients with subclinical thyroid involvement which might later progress to thyroid failure, and this raises the question of the significance to be attached to a positive fluorescent test for thyroid microsomal antibodies. The correlation of these antibodies with a diminished response to thyrotrophin suggests that they are reliable indicators of thyroid disease. In the absence of thyroid biopsy data we can only assume that this disease is a focal lymphocytic thyroiditis, since the necropsy studies of Bastenie et al. (1967) have shown a close correlation, in elderly subjects, between the presence of thyroid autoantibodies and this type of thyroiditis.

It remains to be seen how frequently subclinical thyroid disease progresses to thyroid destruction and clinical myxoedema. For clinical as well as research purposes further follow-up studies are needed in such cases as these, where autoantibodies have been found or an impaired thyroid reserve has been demonstrated. The unexpected discovery of thyroid microsomal antibodies can certainly give useful warning of developing thyroid disease, as in a patient of ours (unpublished) whose thyroid antibodies were found during the investigation of an episode of thrombocytopenic purpura one year before she developed a recognizable goitre due to Hashimoto's disease. Autoantibody screening tests seem therefore to be indicated in all cases of Addison's disease, not only for the easier recognition of an associated pernicious anaemia or hypoparathyroidism but also as a means of identifying thyroid disease, whether latent or clinically evident.

We thank Dr. P. M. F. Bishop and other colleagues, who allowed us to study patients under their care. We are grateful to $\mathbf{M r}$. $\mathbf{K}$. Wood, of the interdepartmental laboratory, and Mrs. Lynn Jones, of the hospital physics department, for technical assistance.

\section{REFERENCES}

Anderson, J. R., Goudie, R. B., Gray, K. G., and Timbury, G. C. (1957) Lancet, 1, 1123.

Bastenie, P. A., Neve, P., Bonnyns, M., Vanhaelst, L., and Chailly, M. (1967). Lancet, 1, 915.

Carpenter, C. C. J., et al. (1964). Medicine, 43, 153.

Colover, J., and Glynn, L. E. (1958). Immunology, 1, 172.

Falta, W. (1912). Berliner Klinische Wochenschrift, 2, 1477.

Hobbs, J. R., Bayliss, R. I. S., and Maclagan, N. F. (1963). Lancet, 1,

Irvine, W. J. (1968). Proceedings of the Royal Society of Medicine, 61, 271

Irvine, W. J., Stewart, A. G., and Scarth, L. (1967). Clinical and Experimental Immunology, 2, 31.

Schmidt, M. B. (1926). Verhandlungen der Deutschen Pathologischen Gesellschaft, 21, 212.

Stevens, A., and Maisey, I. (1969). Guy's Hospital Reports. In press.

Williams, E. D., and Doniach, I. (1962). Fournal of Pathology and Bacteriology, 83, 255 . 